\title{
24 Wie wird die geistige Lebensform von Menschen in der Natur wirklich möglich? - Parallelen zwischen John Dewey und Helmuth Plessner
}

\subsection{Die angesichts der Möglichkeit von Evolution neue naturphilosophische Frage: Wie wird die geistige Lebensform von Menschen in der Natur wirklich möglich?}

In den letzten Jahrzehnten ist oft der Anspruch erhoben worden, dass die Biowissenschaften durch ihre neuen methodischen Zugänge die Thematisierung des Lebens und des Geistes übernehmen können. Die Sozial- und Kulturwissenschaften und die Philosophie scheinen in der Thematisierung des Lebens und des Geistes in eine Defensive geraten zu sein, sieht man von Ausnahmen wie Ottmar Ette ab. Die biologisch verstandenen Life Sciences sollen als die Leitwissenschaften die Führung übernehmen. Diese heutige Lage ähnelt der Herausforderung, die der Philosophie im Laufe der Durchsetzung des Darwinismus und der Entwicklung der Theorie der natürlichen Evolution in der ersten Hälfte des 20. Jahrhunderts entstanden war. Leben schien grundsätzlich durch Vorgänge der Anpassung und Selektion erklärt werden zu können, und wenn es in diesem Leben überhaupt noch Geist gab, dann hatte er eine Funktion des Überlebens zu erfüllen, wenn er nicht aussterben wollte. Über die behavioristischen Modelle für das Verhalten zwischen Organismus und Umwelt hinausgehend zeichnete sich schon damals ab, dass das Leben als ein funktionaler Zusammenhang von Systemen konzipiert werden kann, den man von unten nach oben und von oben nach unten zu durchlaufen hat. In solchen funktionalen Modellen der Emergenz von bottom-up und top-down wird noch heute gedacht, nur dass die operationalen Methoden des Zugriffs immer reduktiver werden, berücksichtigt man in der Gegenwart auch die synthetische Biologie.

Eine Gemeinsamkeit von John Dewey und Helmuth Plessner, die sich nicht gegenseitig beeinflusst haben, sondern unabhängig voneinander philosophierten, besteht darin, dass sie die biowissenschaftlichen Fortschritte begrüßt haben. Sie würdigten sowohl den Erkenntniswert als auch die operationalen Potentiale der Biowissenschaften, die sich technisch, ökonomisch, sozial, kulturell und politisch verwenden ließen, vor allem in der Medizin. Gerade angesichts dieser bereits eingetretenen oder absehbaren Auswirkungen des biologischevolutionären Paradigmas vom Leben sahen sie ihre philosophische Aufgabe 
darin, es in seinen legitimen Grenzen anzuerkennen. Die Philosophie beschäftigt sich mit dem Selbst- und Weltverständnis im Ganzen im Hinblick auf die Lebensführung von Personen (Dewey 1917; Plessner 1985e). Sie berät mündige Bürger in ihrer Lebensführung, insofern letztere diesen im Guten wie im Schlechten problematisch wird und daher in Fragen nach einem weiteren Selbst- und Weltverständnis im Ganzen führt. Dewey und Plessner bejahten die Moderne im Sinne einer konfliktträchtigen Gesellschaft, in der viele Geltungsansprüche aufeinander treffen, wofür man institutionelle Vorkehrungen braucht. Beide orientierten sich an einer öffentlich anspruchsvollen Demokratie, die den freien Austausch zwischen verschiedenen Laien- und Expertenkulturen einschließt (Dewey 1988d; Plessner 1981b u. 1985b). Sie habe die Grundrechte der Menschen als Personen angesichts der Pluralisierung kultureller Autoritäten und der Individualisierung der Lebensführung zu sichern. Dieser Maßstab führte unweigerlich zur Kritik an jeder oligarchischen Durchsetzung irgendeines Paradigmas, auch der natürlichen Evolution, auf geistig-kulturellem, wissenschaftlich-technischem, ökonomischem oder politischem Gebiet (Krüger 2001, 2004c u. 2009b).

Was bedeutete nun aber diese moderne Lebenshaltung im Umgang mit dem biologisch-evolutionären Paradigma des Lebens in ihrer philosophischen Artikulation und Durchführung? - Sie bedeutet eine neue Aufgabe der Philosophie, das Ganze des Selbst- und Weltverständnisses im Hinblick auf die Lebensführung zu denken. Nehmen wir einmal an, die Annahme der natürlichen Evolution hätte grundsätzlich Recht, dann würde dies bedeuten, dass der Mensch als eine geistige Lebensform in der lebendigen Natur entstanden ist und sich als eine solche Lebensform in dieser Natur halten können muss. Aber wie war dies und wie ist dies immer wieder von neuem wirklich möglich?

Um dieser Frage philosophisch, nicht naturwissenschaftlich nachgehen zu können, war zunächst ein Zugang zum Thema des Lebens erforderlich. Das Leben war aber in dem dualistischen Mainstream der modernen Philosophie seit Descartes und Kant exklusiven Fehlalternativen zum Opfer gefallen. Etwas sollte entweder physisch oder psychisch, entweder materiell oder geistig sein, d. h. es konnte nicht leben. William James hatte dagegen und schon vor Dewey die Philosophie des „Und“ in einer neuen Thematisierung von Erfahrung entwickelt (James 1977). Max Scheler hatte vor Plessner die philosophische Untersuchung von lebendigen Phänomenen, die sich selbst zeigen können, gegen die vollständigen Disjunktionen des Dualismus neutralisiert (Scheler 2003 u. 2008). Damit war grundsätzlich ein Zugang zum Leben eröffnet worden, den Dewey und Plessner auf ihre Weise modifizieren. Als lebendig kandidiert zunächst, was sowohl physisch als auch psychisch, sowohl materiell als auch geistig ist. 
Damit ging es aber nicht mehr allein um einen Zugang zum Thema des Lebens, sondern auch um einen neuen Zugang zu dem Thema des Geistes. Geist konnte nicht mehr nur als außerhalb und unabhängig vom irdischen Leben angenommen werden, wie er einem in der Introspektion des je eigenen Bewusstseins oder in der Ausübung einer Religion mit anderen gewiss zu sein scheint. Natürlich blieb die Freiheit von Religion und Weltanschauung jedem Menschen privat und in Gemeinschaft überlassen, aber das philosophische Untersuchungsverfahren, das sich an alle richtet, hat öffentlich mehr zu leisten. Geist musste öffentlich, inmitten der Pluralisierung und Individualisierung von Leben, erfahrbar und konzipierbar werden können. Dafür musste das öffentliche Verhalten unter Personen von behavioristischen Reduktionen befreit werden (Plessner 1983f; Dewey 1988a, 218-228, 234f.). Vor allem aber galt es konstruktiv, dieses öffentliche Verhalten für seine Thematisierung durch eine Semiotik dreistelliger Zeichenrelationen (Dewey 1988c) oder eine „Ästhesiologie des Geistes“ in dreistelligen Symbolfunktionen (Plessner 1980b) für das Verstehen von Personen zu öffnen. Sprache ist zwar das gebräuchlichste Medium dreistelliger Relationen von Syntax, Semantik und Pragmatik, aber nicht die einzige „Symbolform“ des Geistes, wenn man auch Mythen, Religionen, Techniken, bildende und darstellende Künste, Literaturen, Musiken, Tänze u.v.m. (Plessner 1980a) berücksichtigt.

Sowohl Dewey als auch Plessner kritisierten scharf Missverständnisse der Herausforderung durch das biologische Evolutionsparadigma. Die beiden am weitesten verbreiteten Reaktionen auf die Herausforderung bestanden darin, dass man dachte, nun entweder alles dem Inhalte nach biologisieren zu müssen oder die Evolutionstheorie als Form der Erklärung auf andere Bereiche wie die soziokulturelle Entwicklung übertragen zu müssen (Dewey 1909). In beiden Fällen eines inhaltlichen, auch objekt-theoretisch genannten, oder formalen, auch als meta-theoretisch bezeichneten, Biologismus wurde das freie Philosophieren in einer freien Demokratie zugunsten einer selbst ernannten Herrscherelite mit Wahrheitsmonopol abgeschafft. Der Biologismus kann nicht mehr verstehen, wieso es erst jetzt und nicht schon früher $\mathrm{zu}$ ihm selbst gekommen ist und warum er nicht das Ende der Forschung und Geschichte darstellen muss. Er steckt in dem schlechten Zirkel, dass seine begrifflichen Annahmen, nach denen eine Veränderung als Evolution erklärt werden soll, schon in der lebendigen Natur als vorhandene Kausalmechanismen vorausgesetzt werden. Durch die Konfusion der eigenen, erst zu erbringenden Erklärungsleistung mit den Seinsweisen der Natur entzieht sich der Biologismus jeder wissenschaftlichen Überprüfung durch Nachweispflichten (Plessner 1975, 7). Er wird zu einer 
Ideologie, an deren absolute Wahrheit man nur glauben, die man nicht öffentlich überprüfen kann.

\subsection{Die hypothetische Antwort durch die Umstellung der Frage: Die geistige Lebensform von Menschen antwortet auf einen erfahrbaren Bruch im Verhalten der Natur}

Im Gegensatz zu inhaltlichen und formalen Biologismen bestehen Dewey und Plessner auf der antireduktionistischen und antidualistischen Formulierung der folgenden philosophischen Aufgabe: Wie ist Geist, und zwar als ein durch Symbolformen qualitativ irreduzibles Phänomen, in der lebendigen Natur, also nicht außerhalb und unabhängig von ihr, sondern in dem - durch die Einheit der Dualismen - qualitativ irreduziblen Verhalten des Lebendigen, wirklich möglich, also nicht nur auf eine spekulative, die Erfahrung allein überschreitende Weise zu denken? - Wenn die Aufgabe so gestellt wird, muss alles gegenüber dem dualistischen Mainstream der modernen Philosophie neu gedacht werden. Dann kann Natur nicht mehr dasjenige sein, als was sie im Dualismus ausschließlich galt, eben als Materie oder Physisches. Sie musste neu, nämlich als offen für die qualitative Irreduzibilität sowohl des Lebens als auch des Geistes konzipiert werden. Anders wäre in der Natur Evolution nicht wirklich möglich. Diese Natur als Rahmen für Thematisierungen kann nicht aus nichts anderem als einem einzigen mechanischen Determinismus bestehen, was der qualitativen Verunmöglichung von Leben und Geist gleichkäme und zudem die Unveränderlichkeit der anorganischen Natur zum Dogma erheben würde. Die mechanizistische Fehlidentifikation der Natur war eine historische Überverallgemeinerung der menschlichen Teleologie, selber etwas nach dem Zweck-Mittel-Schema mechanisch bewirken zu können. Gott oder der erste Beweger diente der Entgrenzung dieser Teleologie von ihrer Endlichkeit, Bedingtheit und Bestimmtheit, wodurch sie auf das Ganze übertragbar schien und Natur in die Rolle der Materie geraten war. William James hatte gegen dieses „Block-Universum“ der Herrschaft die gleiche Berechtigung für seine Gegen-Hypothese von einem offenen „Pluriversum“ entwickelt, in dem es Spielraum für Neues und nicht allein die ewige Wiederkehr des Gleichen gibt (James 1977).

Wenn Natur als Rahmen für das thematisierbare Ganze verstanden wird und wenn die Aufgabe darin besteht, in dieser Natur so etwas wie eine Evolution von Leben und Geist als wirkliche Möglichkeit zu begreifen, dann gerät diese Natur in die Rolle einer Fraglichkeit, nicht einer letzten Antwort. Die Natur ist 
nicht nur in dem Sinne fraglich, dass wir noch nicht wissen, wie wir aus ihr hervorgehen konnten und uns in ihr halten können, als ob wir dies in einigen Jahrzehnten endgültig wissen und endgültig bewerkstelligen könnten. Könnten wir dies, würden wir uns erneut mit Gott verwechseln und vermeintlich dem Menschen sein endgültiges Ende bereiten. Demgegenüber stellen Plessner und Dewey diese Fraglichkeit der Natur grundsätzlich um. Diese Natur stellt Menschen auf Dauer in ihrem Verhalten in Frage, weshalb diese darauf zu antworten versuchen, indem sie besser oder schlechter ein Leben geistig führen. Die Natur, die die geistige Lebensform in Frage stellt und antworten lässt, kann nichts Homogenes sein. Sie muss, als Ermöglichung personalen Lebens verstanden, in eine Art und Weise von „Bruch“ (Plessner 1975, 292) mit der lebendigen Natur oder von „Differenz“ zu ihr (Dewey 1988b, chapt.2) führen. Dieser Hiatus oder diese strukturelle Differenz bedürfen dann tätiger und kontemplativer Formen, darauf zu antworten. Vor der Frage des Menschen als dem Fragenden gegenüber der Natur als der Antwortenden liegt logisch betrachtet diejenige Natur, die den Menschen in seinem Verhalten in Frage stellt, worauf er in seiner Lebensführung geistig antwortet.

Diese Umstellung und darin Vorverlegung der Frage wäre rein spekulativ, wenn sie nicht über die Erfahrungen vermittelt werden würde, was aber sowohl bei Dewey als auch bei Plessner der Fall ist. Die Relationen zwischen Fragen und Antworten werden erfahrungsabhängig verstanden, d. h. selber im geschichtlichen Lebensprozess und seiner geistigen Spezifik situiert. Damit ist es ausgeschlossen, allein im Namen eines reinen Geistes, der außerhalb und unabhängig von allem Leben auf Dauer bestehen könnte, sprechen, handeln, erkennen zu können. Ist Menschen diese göttliche Position aber verwehrt, müssen sie sich an ihre Erfahrungen und deren lebendige und geistige Qualitäten im Medium einer offenen Geschichte halten. Was Dewey das Qualitative der Erfahrungen nannte, bezeichnete Plessner als den Anschauungscharakter der Erfahrungen. Plessner kam zwar aus der phänomenologischen Tradition, verstand sie aber nicht dualistisch, sondern verwendete die Phänomenologie nur als eine Methode dafür, das Qualitative von Erfahrungen zu beschreiben (Plessner 1975, 30, 126), was mit Deweys Auffassung kompatibel ist (zum phänomenologischen Erbe von W. James in Dewey siehe Bernstein 2010, 137).

Dewey und Plessner sahen die Stärke der Naturwissenschaften darin, Erfahrungen auf eine operationale Weise unter bestimmten Bedingungen reproduzierbar machen zu können. Erfahrungen wurden von ihren Qualitäten, die sie in Kontexten der Lebensführung besaßen, befreit und in Kontinua überführt, die man methodisch darstellen und messen kann (Plessner 1975, 26, 118-120). Dadurch konnten Bedingungsgefüge intelligent transformiert werden (Campbell 
1995). Diese emanzipatorische Leistung der Naturwissenschaft und Technik setzte aber nach wie vor die Erfahrung von Qualitäten in der Lebensführung der Personen voraus, ohne die sich niemand orientieren könnte. Qualitäten werden öffentlich in Situationen erfahren, in denen man sich verhält, nicht erst in Empfindungen, die man privat im je eigenen inneren Bewusstsein empfindet, sei es im Guten wie bei einem mitreißenden Konzert, sei es im Schlechten wie in einer Massenkarambolage. Sowohl die Forscher selbst brauchen weiterhin qualitative Erfahrungen als Forscher, etwa die Liebe zu ihrem Gegenstand, umso mehr in ihrer Lebensführung als Personen wie alle anderen Personen auch, im Schwimmen, beim Essen, während eines Vortrags, in Freundschaft, Krankheit, im Glück und beim Sterben ihrer Nächsten. Auch die Anwendungen der Forschungsresultate müssen in qualitativen Erfahrungskontexten für andere Personen rekontextualisiert werden können, sollen sie für die Betroffenen lebensfördernde statt lebenszerstörende Auswirkungen haben. Die Genexpressionen und Hormonproportionen, die geschlechtliche Liebe als physisches Korrelat zweifellos begleiten, nehmen den betroffenen Personen nicht die qualitative Erfahrung ihrer Liebe ab. Die philosophische Aufgabe in der Kooperation mit den Biowissenschaften bestand für Plessner und Dewey darin, die lebendige und geistige Qualität von Erfahrungen so zu erfassen und kategorial zu ordnen, dass sich ihr Zusammenhang mit dem Selbst- und Weltverständnis im Hinblick auf die Lebensführung ausarbeiten ließ.

\subsection{Die menschliche Existenz erfahre Natur als unauflösliche Differenz und Unbekannte im Ganzen (Dewey)}

Sidney Hook schrieb in seiner Einleitung in Deweys Experience and Nature, dass dieses Buch die vielversprechendste und schwierigste Zusammenfassung dieser Philosophie darstelle, an der sich die Einwände feindlicher Kritiken und die verschiedensten Interpretationen sympathisierender Kritiken entzündet haben (Dewey 1988b, vii). Gerade deshalb beziehe ich mich im Folgenden auf dieses Buch. In der unvollendeten Einleitung zur Neuausgabe (1949-51) ersetzt Dewey den alten durch den neuen Titel „Culture and Nature“ (ebd., 361), weil der Begriff der „Erfahrung“ aus „historischen“ Gründen mit etwas Psychischem (im Gegensatz zum Physischen) und etwas privat Mentalem (im Gegensatz zum Materiellen) verstanden werde. Demgegenüber habe er unter „Erfahrung“ aus „theoretischen Gründen“ den inklusiven und qualitativen Zusammenhang zwischen dem „Was“ und dem „Wie“ im öffentlich zugänglichen Verhalten 
(conduct) begriffen (Dewey 1988b, 362). Diesen einheitlichen Zusammenhang der verschiedensten Aspekte könne man inzwischen besser durch den ,anthropologischen“ Begriff der „Kultur“ artikulieren, wenn man darunter mit Bronislaw Malinowski den ganzheitlichen Zusammenhang zwischen materieller und ideeller Kultur verstehe (ebd. 363), ihn also nicht - wie schon den Erfahrungsbegriff - erneut in dualistische Fehlalternativen auflöse. Diese Ersetzung des Erfahrungs- durch den Kulturbegriff hatte Dewey bereits in der Ausgabe von 1929 erwogen, als er zustimmend Alexander Goldenweiser wie folgt zitierte:

\footnotetext{
'Cultural reality is never wholly deterministic nor yet wholly accidental, never wholly psychological nor yet wholly objective, never wholly of yesterday nor yet wholly of today, but combines all of these in its existential reality [...]. A reconstructive synthesis reestablishes the synthetic unity necessarily lost in the process of analytic dismemberment.' (Dewey 1988b, 42)
}

Dewey ging es 1929 und 1949-51 um die Artikulation eines einheitlichen und öffentlich zugänglichen Zusammenhanges, der in sich qualitativ differenziert werden kann, ohne in die allein ausschließlichen Alternativen aufgelöst werden zu können. Auch der Kulturbegriff sollte also gerade nicht den Menschen einsperren und von der Natur abtrennen, als würde der Mensch vollständig durch Kultur determiniert. Kulturmuster ermöglichen Erfahrung, indem man eine Abweichung oder Bestätigung dieser Muster erfährt, aber so, dass diese Abweichung oder Bestätigung für einen selbst qualitativ unersetzbar wird. An dieser theoretischen Funktion eines qualitativ differenzierbaren Ganzen in Deweys Kategorie hat sich nichts geändert, wohl aber an seiner Berücksichtigung des historisch dominanten Gebrauchs von bestimmten Begriffen durch Andere. Man könnte heute sagen, dass auch der Kulturbegriff wieder dualistisch aufgelöst worden ist, was in der empirisch-analytischen Arbeit unvermeidlich $\mathrm{zu}$ sein scheint. Aber dies würde nichts an der philosophischen Aufgabe ändern, gegen die Vollständigkeit der Auflösung erneut den synthetisierenden Zusammenhang der Teile in einem qualitativen Sinne zu rekonstruieren. Diese Aufgabe, die Dewey der Philosophie gestellt hat, hat Richard Rorty nicht geteilt. Er dachte, dass der Weg zur sprachlichen Selbsterschaffung frei sei, wenn endlich die Metaphysik der Erfahrung, die uns Sprachbenutzer noch in den Zusammenhang der Natur stellt, über Bord geworfen wird. Die Natur könne man getrost den Naturwissenschaften überlassen (Rorty 1989 u. 1998). Dagegen haben Hilary Putnam (1995), Richard Shusterman (2008) und Richard Bernstein (2010) überzeugend gezeigt, dass diese dualistische Auflösung in sprachliche Selbsterschaffung und Naturkausalität nichts mit Deweys theoretischer Funktion zu tun 
hat, in dem einheitlichen Kontinuum der Natur qualitative Differenzen zu erfassen, weshalb sie seinen Erfahrungsbegriff reaktualisiert haben.

Nach dem einleitenden Kapitel über die experimentelle Methode, an der Dewey auch die Philosophie orientiert, führt er in sein Verständnis von der Natur als des Rahmens der menschlichen Existenz ein. Diese Natur wird im zweiten Kapitel in immer neuen Variationen als eine unauflösbare Differenz beschrieben. Alles, was von dieser Natur für Menschen in der Erfahrung als Existenz zugänglich werde, werde dies in der Differenz ,as Precarious and as Stable“ (Dewey 1988b, 42), wie das Kapitel schon im Titel heißt. Im Anschluss an die anthropologischen Untersuchungen vormoderner Kulturen schreibt Dewey im Hinblick auf „the origin of philosophy“: „We confine ourselves to one outstanding fact: the evidence that the world of empirical things includes the uncertain, unpredictable, uncontrollable, and hazardous“ (ebd., 43). Dieses Faktum könne man nicht als Aberglauben abtun, den es seit dem Zeitalter der Vernunft, Wissenschaft und Technik nicht mehr gebe. „These things are as true today as they were in the days of early culture. It is not the facts which have changed, but the methods of insurance, regulation and acknowledgement“ (ebd., 44). Auch in der modernen Welt, man denke nur an die Atmosphäre einer künstlerischen Installation oder den Unterschied zwischen quantenmechanischer und relativitätstheoretischer Physik, verstehe man etwas, das hier und jetzt anwesend ist, im Kontrast und Zusammenhang mit dem, was abwesend ist, wenngleich diese strukturelle Differenz anders als magisch interpretiert werde. Im Anschluss an Herbert Spencers kulturgeschichtliche Vergleiche schreibt Dewey:

The visible is set in the invisible; and in the end what is unseen decides what happens in the seen; the tangible rests precariously upon the untouched and ungrasped. The contrast and the maladjustment of the immediate, the conspicuous and focal phase of things, whith those indirect and hidden factors which determine the origin and career of what is present, are indestructible features of any and every experience. (Ebd., 44)

Was Dewey nun den traditionellen Philosophien von der antiken Klassik bis in die Gegenwart vorwirft, besteht darin, „that their diversity is due to acceptance of a common premise. Variant philosophies may be looked at as different ways of supplying recipes for denying to the universe the character of contingency which it posseses so integrally“ (ebd., 46). Die unauflösliche Differenz werde aufgelöst zugunsten einer, nämlich der jeweils angenehmeren ihrer Seiten.

As against this common identification of reality with what is sure, regular and finished, experience in unsophisticated forms gives evidence of a different world and points to a different metaphysics. We live in a world which is in an impressive and irrestistable mix- 
ture of sufficiencies, tight completenesses, order, recurrences which make possible prediction and control, and singularities, ambiguities, uncertain possibilities, processes going on to consequences as yet indeterminate. They are mixed not mechanically but vitally [...]. Qualities have defects as necessary conditions of their excellencies; the instrumentalities of truth are the causes of error; change gives meaning to permanence and recurrence makes novelty possible. A world that was wholly risky would be a world in which adventure is impossible, and only a living world can include death. Such facts have been celebrated by thinkers like Heracleitus and Lao-tze. (Ebd., 47)

Dewey geht sodann die verschiedenen traditionellen Philosophien von der Antike bis zur Gegenwart durch, um ihre verschiedenen, aber immer einseitigen Auflösungen der Problemlage der menschlichen Existenz herauszuarbeiten, was wir hier nicht überprüfen können. Wichtig für seinen eigenen theoretischen Zugang ist, dass er den grundsätzlich differentiellen Charakter der menschlichen Existenz verteidigt, d. h. ihre Fraglichkeit, die über jeden Versuch, diese Fraglichkeit endgültig in einer positiven Antwort feststellen zu können, geschichtlich erneut hinausführt. Seine Kritik betrifft das falsche Versprechen, die menschliche Existenz, die von Erfahrungen der Natur und in der Natur im weiten Sinne lebt, durch was auch immer (Mythos, Kontemplation, Mechanizismus, Rationalismus) von ihrem problematischen Charakter endgültig befreien $\mathrm{zu}$ können. Dewey vertritt gegen diese Versprechen, die alle nicht eingelöst werden konnten, eine klare Gegenposition: Das Ganze der Natur, das von der menschlichen Existenz in ihr erfahren werden kann, bleibt eine Unbekannte. Um dieses Ganze erkennen zu können, müsste man außerhalb desselben stehen, womit es schon nicht mehr das Ganze wäre. Er vertritt einen Holismus, aber einen negativen Holismus. Das Ganze bleibt offen in den genannten, für die menschliche Existenz unauflöslichen Differenzen, weshalb diese Existenz stets vor der erneuten Aufgabe ihrer Verbesserung steht. In der Annahme dieser Herausforderung halte sich die menschliche Existenz auch in Zukunft am Leben und im Geiste. So kann sie in jeder geschichtlich problematischen Situation stets von neuem antworten, Besseres und Schlechteres komparativ unterscheiden lernen, ohne sich ein absolutes Ende zu bereiten, das jede Erfahrungsmöglichkeit übersteigt (ebd., 56-62).

\subsection{Drei Plateaus von Interaktionsfeldern im Verständnis der Natur (Dewey)}

Dewey sieht seine philosophische Aufgabe nicht darin, eine „causal explanation" (Dewey 1988b, 209) für die Emergenz des Geistes (207, die im folgenden Text in Klammern gesetzten Seitenzahlen beziehen sich auf Dewey 1988b) zu 
leisten, sondern darin, Kategorien zu entwickeln, die empirische Deskription (208) für das Verstehen der neuen Problemlage ermöglichen, d. h. für „,an understanding of the adaptation of nature and life and mind to one another" (ebd., 211). Dafür unterscheidet er zwischen mindestens drei Ebenen an Interaktionen:

\begin{abstract}
In general, three plateaus of such fields may be discriminated. The first, the scene of narrower and more external interactions, while qualitatively diversified in itself, is physical; its distinctive properties are those of the mathematical-mechanical system discovered by physics and which define matter as a general character. The second level is that of life. Qualitative differences, like those of plant and animal, lower and higher animal forms are here even more conspicuous; but in spite of their variety they have qualities in common which define the psycho-physical. The third plateau is that of association, communication, participation. This is still further internally diversified, consisting of individualities. It is marked throughout its diversities, how ever, by common properties, which define mind as intellect; posession of and response to meanings. (Ebd. 208)
\end{abstract}

Die zweite und dritte Ebene enthalten keine zusätzliche Energie im physikalisch-chemischen Sinne (ebd., 195), sondern schließen als notwendige Bedingung die erste Ebene ein. Sie stellen nicht irgendwelche Mischungen aus Bestandteilen (Physikalischem und Psychischem, Lebendigem und Geistigem), sondern neue Funktionen durch Organisation und erlernbares Verhalten dar. Dadurch ändert sich „the way“, wie eine Aktivitätsart (lebendige, geistige) und ihre „consequences“ (ebd., 195) im zeitlichen Gesamtverlauf zusammenhängen. Die dritte Ebene schließt als notwendigen Bestandteil auch die zweite Ebene ein (ebd., 212). Umgekehrt kann die erste Ebene ohne die beiden anderen existieren, oder kann die zweite mit der ersten ohne die dritte Ebene vorkommen.

Ein Organismus besteht aus Teilen, von denen jeder „,is itself organized“: „Hence its selective bias in interactions with environing things is exercised so as to maintan itself, while also maintaining the whole of which it is a member" (ebd., 196). Dies erfordert eine „pervasive operative presence of the whole in the part and of the part in the whole", die auf verschiedenen Niveaus erreicht werden kann. Je nach Ausdifferenzierung von sensorischen und motorischen Organen, von proprio- und exterio-zeptorischen Organen (ebd., 199), unter letzteren wieder für Kontakt- und Distanzaktivitäten, gibt es verschiedene Weisen, in denen die „preparatory“ und ,anticipatory activities“ in Empfindungen, Gefühlen und Stimmungen integriert werden.

As life is a character of events in a peculiar condition of organization, and ,feeling ' is a quality of life-forms marked by complexly mobile and discriminating responses, so ,mind is an added property assumed by a feeling creature, when it reaches that organized interaction with other living creatures which is language, communication. Then the qualities 
of feeling become significant of objective differences in external things and of episodes past and to come. (Ebd., 198)

Dewey versteht Sprache als eine kooperative Interaktionsweise in einer mindestens triadischen Beziehung. Es gibt Sprecher und Hörer, die im Hinblick auf etwas Drittes kooperieren, sei dieses ein Ding, z. B. eine „flower“ (ebd., 140), oder eine weitere Person wie in der ,jurisdiction“ (ebd., 154). Die triadische Kooperation im Vordergrund „presupposes an organized group to which these creatures belong, and from whom they have acquired their habits of speech": Language „is therefore a relationship, not a particularity“ (ebd., 145). Die Teilnahme an dieser Beziehung erfordert, dass sich jeder „puts himself at the standpont of a situation in which two parties share“: „To understand is to anticipate together, it is to make a cross-reference which, when acted upon, brings about a partaking in a common, inclusive, undertaking“ (ebd., 141). Dewey spricht sich scharf gegen die Trennung instrumentaler und final erfüllender Funktionen aus, weil es sich dabei um künstliche Zeichensprachen für spezielle Zwecke handelt. Die in der Lebensführung unersetzliche Sprache sei Kommunikation:

Communication is uniquely instrumental and uniquely final. It is instrumental as liberating us from the otherwise overwhelming pressure of events and enabling us to live in a world of things that have meaning. It is final as a sharing in the objects and arts precious to a community, a sharing whereby meanings are enhanced, deepened and solidified in the sense of communion. Because of its characteristic agency and finality, communication and its congenial objects are objects ultimately worthy of awe, admiration, and loyal appreciation. (Ebd., 159)

In diesem Verständnis der Umgangssprache als Kommunikation wird schon deutlich, dass „Geist“ bei Dewey die bleibende Präsupposition dafür bildet, triadische Zeichen in analytische Teile zerlegen zu können, die sich gegenseitig ausschließende Bedeutungen haben, ohne dass sich das Ganze schlichtweg auflöst. Geist dürfe insbesondere nicht vom aktualen Bewusstsein der Individuen her verstanden werden, und dies nicht nur, weil das tierliche Bewusstsein unmittelbar gefühlter Qualitäten nicht mit dem menschlichen Bewusstsein verwechselt werden sollte.

Mind denotes the whole system of meanings as they are embodied in the workings of organic life; consciousness in a being with language denotes awareness or perception of meanings; it is the perception of actual events, whether past, contemporary or future, in their meanings, the having of actual ideas. The greater part of mind is only implicit in any conscious act or state; the field of mind - of operative meanings - is enourmously wider than that of consciousness. Mind is contextual and persistent; consciousness is focal and 
transitive. Mind is, so to speak, structural, substantial; a constant background and foreground; perceptive consciousness is process, a series of heres and nows. Mind is a constant luminosity; consciousness intermittand, a series of flashes of varying intensities. (Ebd., 230)

So verstanden ermöglicht das Bewusstsein hier und jetzt eine „undergoing redirection of meaning“, die aber das ganze System von Bedeutungen im Leben, also Geist, voraussetzt (ebd., 233, 235).

Geist existiert in kommunikativen Beziehungen, deren instrumentelle und finale Funktionen symbolisch-praktisch ausdifferenziert werden können. So sind für Dewey die Erfahrungswissenschaften und Techniken darauf fokussiert, die Zweck-Mittel-Relationen zu verbessern, und die ästhetischen Künste darauf, die finalen Erfüllungen in einer ganzheitlichen Erfahrung zu vervollkommnen. Aber all diese arbeitsteiligen Spezialisierungen haben für Dewey letztlich keinen Selbstzweck. Sie stellen Beiträge für die Lösung problematischer Situationen dar, die in der menschlichen Existenz auftreten und der öffentlichen Organisation bedürfen, wenn die indirekten Handlungsfolgen über das Private hinausgehen (Dewey 1988d). Die drei Ebenen der menschlichen Existenz in der Natur müssen je nach neu erfahrener Differenz zwischen dem Prekären und dem Stabilen integriert werden können. Dafür braucht man sowohl eine intelligente Kritik der bisherigen Zweck-Mittel-Relationen, indem man die Folgen und Konsequenzen nicht nur der Mittel, sondern auch der Zwecke in Frage stellt, als auch ästhetisch-künstlerische Experimente, die die finale Erfüllung in ganzheitlicher Erfahrung, d.h. die Wertbildung, verbessern. Dewey sieht die Aufgabe seiner Philosophie in einer allgemeinen Kritik der vorausgesetzten Werte, deren Erfüllung bestimmte Zweck-Mittel-Relationen legitimiert, die dadurch schon nicht mehr in Frage gestellt werden.

In der dualistischen Moderne gilt als ein besonders hoch zu schätzender Wert der, Subjekt zu sein. Dies hält Dewey für einen „impass in life“ (ebd., 186), für ,a snare and peril“ (ebd., 315), wenn darunter verstanden wird, dass das innere Bewusstsein von Individuen als Zuschauer seiner selbst abgelöst wird von all seinen Existenzbedingungen in der Natur und zum Maßstab für die Natur erhoben wird. Das Modell, Zuschauer seiner selbst zu sein, statt Teilnehmer seiner geistigen Lebensführung in der Natur zu werden, nennt Dewey das Modell vom „kleinen Gott“. Die Übertragung dieses Modells auf die Natur im Ganzen, so dass es zum Maßstab für die Natur selber wird, nennt Dewey die Selbstvergötterung des Menschen zu „Gott“ (im Anschluss an Richter Oliver Wendell Holmes, 312f.). Um diesen Modellen für das Selbst- und Weltverständnis zu folgen, braucht man keineswegs religiös zu sein, echt religiös Gläubige können diese Modelle leicht für Blasphemie halten. Dieses Selbstverständnis durchzieht 
auch Weltanschauungen, die sich nicht für religiös halten, weil Wissenschaft, Technik und/oder Künste die Rolle einer phantastischen Allmacht und Allwissenheit übernehmen können.

When man finds that he is not a little god in his active powers and accomplishments, he retains his former conceit by hugging to his bosom the notion that nevertheless in some realm, be it knowledge or esthetic contemplation, he is still outside of and detached from the ongoing sweep of inter-acting and changing events; and being there alone and irresponsible save to himself, is as god. When he perceives clearly and adaequateley that he is within nature, a part of its interactions, he sees that the line to be drawn is not between action and thought, or action and appreciation, but between blind, slavish, meaningless action and action that is free, significant, directed and responsible. (Ebd., 324)

Dewey bekräftigt in seinem Abschlusskapitel über die Wertekritik seinen Ausgangspunkt von der unauflöslichen Differenz in der Erfahrung der Natur als des Rahmens der menschlichen Existenz. Die Harmonie, nach der man unentwegt strebt, weil es gleichursprünglich schon immer Disharmonie gebe, verwandle Philosophie, so Dewey Holmes zitierend, in „the chords of a harmony that breathes from the unknown“ (ebd., 313). Das Ganze der erfahrbaren Natur bleibt das Unbekannte in unauflöslichen Differenzen. Der Versuchung durch Harmoniesucht, mehr versprechen zu dürfen, widersteht Dewey am Rande dieser Klänge.

[While] philosophy has its source not in any special impulse or staked-off section of experience, but in the entire human predicament, this human situation falls wholly within nature. It reflects the traits of nature, it gives indisputable evidence that in nature itself qualities and relations, individualities and uniformities, finalities and efficacies, contingencies and necessities are inextricably bound together. The harsh conflicts and the happy coincidencies of this interpenetration make experience what it consciously is; their manifest apparition creates doubt, forces inquiry, exacts choice, and imposes liability for the choice which is made. Were the complete harmony in nature, life would be spontanous efflorescence. If disharmony were not in both man and nature, if it were only between them, man would be the ruthless overlord of nature, or its querulous oppressed subject. It is precisely the peculier intermixture of support and frustration of man by nature which constitutes experience. (Ebd., 314)

\subsection{Phänomenologie und Hermeneutik der lebendigen Natur in Plessners Naturphilosophie}

In dem folgenden Abschnitt werden wir sehen, dass Plessner in seinem naturphilosophischen Hauptwerk Die Stufen des Organischen und der Mensch (1928) 
eine Dewey ganz ähnliche qualitative Charakterisierung von Leben unternimmt, aber auf seine originäre Weise. ${ }^{1}$ Plessner, der selbst auch Biologe war, praktiziert hier eine naturphilosophisch teilnehmende Beobachtung der biologischen Forschung, die er von den Gestaltexperimenten (der Physiker und Chemiker an Kristallen, der Gestaltpsychologen an Tieren und Menschen) bis zu der experimentellen Ermittlung der Schimpansen-Intelligenz (seit Wolfgang Köhler) bestens kennt. Deren empirische Erfahrungen zielen auf experimentell darstellbare und messbare Ergebnisse, die die Einrichtung quantifizierbarer Kontinua erfordern. In diesem experimentellen Kontext kann dann auch gegebenenfalls eine kausalanalytische Erklärung erfolgen. Aber diese Resultate setzen voraus, dass man um die qualitative Irreduzibiltät der Phänomene und ihre wesentlichen Unterschiede untereinander in der Anschauung und deren Deutung weiß. Dieses Vorverständnis, das die biologische Forschung ermöglicht und insbesondere erneut in der lebensweltlichen Anwendung der biologischen Ergebnisse relevant wird, teilen die Biowissenschaftler als Personen mit den anderen gebildeten Laien ihrer modernen Soziokultur. Die Naturphilosophie expliziert, so Plessner, dieses lebensweltlich vorausgesetzte und in der Lebensführung nicht ersetzbare Anschauen und Verstehen der Phänomene (Plessner 1975, 34-36, 67) durch ihre „Kategorien“. Kategorien stellen „Formen der Übereinstimmung zwischen heterogenen Sphären, sowohl zwischen Denken und Anschauen wie zwischen Subjekt und Objekt“ (ebd., 116) dar. Sie werden implizit und im Vorverständnis der Biologen in Anspruch genommen, um empirische „Begriffe“ zu bilden (ebd.). Auf solche kausal nicht erklärten, gleichwohl aber qualitativ irreduziblen Phänomene verschiedener Wesensart zielen die drei folgenden Grenzfragen ab, die funktional eine deutliche Verwandtschaft zu den beiden ersten Ebenen bei Dewey erkennen lassen. Auf Deweys dritte Ebene kommen wir in dem 6. Unterkapitel zurück.

1 Auf Englisch hat Marjorie Grene die erste Einführung in Plessners Naturphilosophie (Grene 1974, chapt. XVIII) geschrieben. Einen aktuellen Einblick in Plessners Philosophische Anthropologie bietet das von Richard Shusterman herausgegebene Sonderheft des Journal of Speculative Philosophy (Shusterman 2010), erste Überblicke sind enthalten in Mul 2014 und Honenberger 2016. Jüngst ist auch Plessners Naturphilosophie selber auf Englisch erschienen (Plessner 2019). 


\subsubsection{Hypothese im phänomenologischen Zugang: Körper sind lebendig, insofern sie ihre eigene Grenze vollziehen}

Wie kann der Unterschied zwischen anorganischer und lebender Natur derart begriffen werden, dass - bei aller Gestaltkontinuität zwischen ihnen - anorganische Zusammenhänge in spezifisch lebendige Phänomene funktional integriert werden? Für die Beantwortung dieser Frage entwickelt Plessner die Hypothese, dass Körper in der Anschauung, d. h. in der qualitativen Erfahrung, leben, insofern sie ihre eigene Grenze vollziehen (Plessner 1975, 99-101) Um einen solchen Grenzvollzug anschauen zu können, muss man die Anschauung methodisch fokussieren. Auf der einen Seite gibt es Bestimmungen des Körpers in Raum und Zeit im Sinne der Physik, d. h. im Sinne der Realität. Auf der anderen Seite geht es um den rein geistigen Gehalt von Begriffen wie dem der „Lebendigkeit" des Körpers, um einen Gehalt, der als solcher raum- und zeitlos, mithin irreal ist. Genau zwischen Raum und Zeit einerseits und Raum- und Zeitlosigkeit andererseits liege, so Plessner, das Spektrum der lebendigen Verbindung beider, das „Raumhafte“ (ebd., 85, 127-130, 183, 258) und das „Zeithafte“ (ebd., 171-180, 279f., 319), mithin das für die Lebensführung Wirkliche. Es besteht aus öffentlich beobachtbarem Verhalten, z. B. Bewegungen oder Ruhelagen, die in der Sequenz der Situationen Sinnrichtungen folgen, z. B. aus dem Körper heraus und in ihn hinein. Es geht also um die Dynamik einer Struktur in der Anschauung, und zwar, weil es sich um die Grenze handelt, um den Wechsel zwischen von innen nach außen und von außen nach innen des Körpers, oder zwischen noch nicht und nicht mehr. Körper können, insofern sie in der Anschauung leben, raumhaft über sich hinausgehen und von dort zurück in sich hinein gehen. Sie können zeithaft sich vorweg (das nächste Larvenstadium) und hinter sich her (das letzte Larvenstadium) sein, eben in den Sinnrichtungen ihres Verhaltens. Sie zeigen ihre Raum- und Zeithaftigkeit, indem sie sich gegenüber sie umgebenden Medien öffnen und schließen, also ihre Grenzfunktion vollziehen. Sie entfalten - über ihre anorganische Beschaffenheit hinausgehend und an diese gebunden - einen Grenzübergang in das ihnen Äußere und von dort in das ihnen Innere zurück (siehe ebd., 101-105).

Allerdings kann die Erfüllung dieser Anschauung von Lebendigkeit nur dem Scheine nach vorliegen, weshalb Plessner die phänomenologische durch eine hermeneutische Analyse erweitert (ebd., 121-126). Die Phänomenbeschreibung muss gedeutet werden. Unter welchen ontischen und ontologischen Bedingungen des lebendigen Daseins, die sich unter dem Gesichtspunkt der Grenzhypothese verstehen lassen, wird diese Anschauung von Lebendigkeit zu einer Wirklichkeit, die nicht nur angezeigt wird (ebd., 171-180)? Diese herme- 
neutische Überprüfung des Anschauungsbefundes nennt Plessner die „Deduktion“ der Kategorien des Lebendigen. Man muss in ihr fortwährend von der Anschauung bestimmbarer Phänomene und ihrer ontisch-ontologischen Interpretation gemäß der Grenzhypothese hin und her gehen. Wirklich lebendig wäre der Körper, wenn er sich „positioniert“, indem er nicht nur eine Stelle in der physikalischen Raumzeit ausfüllt, sondern sich von außerhalb und innerhalb dieser Stelle zu ihr verhält. Er würde sie dann als seinen Ort und seine Zeit, als eine Art von Eigenraum und Eigenzeit, „behaupten“ (ebd., 129). Insoweit wäre jeder lebendige Körper „kein bloßes Ding, sondern ein Wesen“, ein „Fürsichsein“ (ebd., 131), dessen Schwierigkeit allerdings darin liegt, es nicht als Bewusstsein oder Selbstbewusstsein denken zu können. Plessner lehnt solche Anthropomorphismen ab.

\subsubsection{Hermeneutische Rekonstruktion: Die Prozessform des Widerspruchs lebendiger Körper}

Wenn man, wie W. James, das Und gegen den Dualismus stark macht, oder wie Scheler und Dewey geistesverwandt schreiben, wenn man sich methodisch gegen das Entweder-physisch-oder-psychisch neutralisieren müsse, dann gerät man gleichwohl in einen Widerspruch, weshalb Plessner betont, dass man den Dualismus nicht abschaffen, sondern nur entfundamentalisieren könne. Er tauge nicht als Fundament, d. h. nicht als Träger der Untersuchung und Begründung, wohl aber als eine operable Unterscheidung (Plessner 1975, 38). Der Widerspruch besteht in Folgendem: Einerseits führt man zwar die Konjunktion zwischen den Gliedern des jeweiligen Dualismus ein, andererseits verwendet man aber weiterhin die exklusive Alternative, mindestens um einen Unterschied zu bezeichnen, damit nicht alles in einer mythenähnlichen oder unmittelbar differenzlosen Einheit zusammenläuft. Erlebnisse können solche Einheitsformen aufweisen, wie Henri Bergson und William James gezeigt haben, nur für Plessner kann man nicht darauf die methodische Überprüfung aufbauen. Wenn der entstandene Widerspruch wirklich ist, dann gilt es nach seinen Existenzbedingungen im modernen Sinne zu fragen. Sie müssen erfahrbar, d. $h$. erfahrungsermöglichend verstanden werden können. Insofern gibt es eine indirekte Überprüfung im Hinblick auf das, was die Naturwissenschaft aus der Wirklichkeit (Qualitäten der Raum- und Zeithaftigkeit) selektiv als Realität (unter Bedingungen reproduzierbare Kontinua) herausschneidet. Modern heißt aber auch, nach der kopernikanischen Wendung, lebendige Körper nicht vom Kosmos, Gott, einem ersten Beweger, einer absoluten Aktualität her zu verste- 
hen, die den lebendigen Körpern nur von außen gleichsam eingehaucht wird, damit ihre Potentialität erwache. Gegen solche romantischen Vitalismen beharrt Plessner darauf, weiterhin vom individuellen Lebewesen auszugehen, das als physischer Körper mit öffentlich zugänglichen Verhaltensqualitäten erfahrungssicher ist.

Wenn alte, vor-kantische Ontologien bei der ontisch-ontologischen Interpretation der Lebendigkeit für die allgemeine Öffentlichkeit problematisch sind, muss man in der widersprüchlichen Verfassung lebendiger Körper selber ansetzen. Diese Wende erinnert zwar an Hegels Dialektik, wird aber von Plessner als eine Dialektik ohne Hegels Aufhebung ins Absolute verstanden (Plessner 1975, $88,113,150 f .$, 305). Wie kann also ein lebender Körper seine widersprüchlichen Momente zur Entfaltung bringen und gleichwohl zu seiner Einheit finden? Ein lebendiger Körper „kann nur sein, indem er wird; der Prozess ist die Weise seines Seins“ (ebd., 132). Im Prozess können sich die widersprechenden Momente des lebendigen Körpers verteilen, und zwar sowohl räumlich und zeitlich als auch raumhaft und zeithaft. Dann gilt ein Antagonismus nicht an ein und derselben Stelle und auch nicht in einer und derselben Sinnrichtung, sondern verteilt auf verschiedene Stellen und in verschiedene Sinnrichtungen für die Dynamik der Struktur. Ein Prozess bedeutet, dass die antagonistischen Teilprozesse im lebenden Körper durch Organisation so unterschieden und zusammengeführt werden, dass der Organismus nach außen und damit im Ganzen sich positionieren kann. Er verteilt und integriert sich im Prozess.

Der dynamisch gerichtete Charakter dieses Prozesses, sein Entwicklungscharakter, wird als der fortwährende „Ausgleich einer Unfertigkeit“ in seiner „Selbstlenkung“ verstanden, die keiner besonderen, im Neovitalismus angenommenen Lebenskraft (ebd., 146) bedarf. Dafür muss aber eine Art und Weise von schon vorbewusster Rückbezüglichkeit des lebendigen Körpers angenommen werden, die ein „systemhaftes Ganzes“ darstellt (ebd., 159). In dem Prozess, der in sich zurückläuft, gibt es dafür die „Funktion der Mitte“, die die wirkliche Möglichkeit des Körpers, d. h. seine Potenz, darstellt (ebd., 161-162): Von solcher „Selbstregulation“ zeugten „Restitutionsphänomene“ und „Adaptationsphänomene“ (ebd., 164). Der lebendige Körper löst sich nicht in seine Teile, die Organe, auf, sondern hat sie zugleich als Mittel in seiner Potentialität und Aktualität im Ganzen. „Erst als Einheit von Zweck und Mittel ist der lebendige Körper Ganzheit oder autonomes System“ (ebd., 171). In der Anschauung begegnen solche Phänomene raumhaft als solche, die sich in einer „Entfaltung“ befinden, und zeithaft als solche, die sich selber vorweg und daher hinterher sind. „In Rückbindung von der Zukunft her steht der lebendige Körper, ihm selber vorweg, d. h. Zweck, seinem dauernden Übergehen vom Noch nicht ins 
Nicht mehr entgegen und beharrt“ (ebd., 180). Das Differential seiner konkreten Gegenwart besteht in einem Augenblick der Einheit von Zukunft und Vergangenheit: „Seine Gegenwart ist jene Aktualität, die nicht mehr im unversöhnlichen Gegensatz zur Potentialität gedacht werden muss, sondern Potentialität zur Voraussetzung hat: erfüllte Potentialität“ (ebd.).

\subsubsection{Vom Organismus-Modell zum Interaktionsmodell in der Hermeneutik des Lebens: Das Zusammenspiel der Organisations- und Positionsformen als Grenzübergang}

Unter Organisationsformen werden die Gliederungen lebendiger Körper dem Sinne nach von innen her und nach innen hin verstanden. Die Positionsformen betreffen die struktur-funktionalen Möglichkeiten dieser Körper, sich nach außen in eine Umwelt hinaus und von außen zurück zu sich positionieren zu können. Wie lässt sich das Zusammenspiel zwischen Organisations- und Positionsformen im Verhalten verstehen? Diese Frage ergibt sich gemäß Plessners Hypothese, lebendige Körper könnten ihre eigene Grenze vollziehen. Dieser Zugang hat den forschungsstrategischen Vorteil, dass er die früheren Organismus-Modelle des Lebens immanent in die anderen Lebensmodelle von der Interaktion des Organismus mit seiner Umwelt überführen kann. „In seinen Organen geht der lebendige Körper aus ihm heraus und $\mathrm{zu}$ ihm zurück, sofern die Organe offen sind und einen Funktionskreis mit dem bilden, dem sie sich öffnen. Offen sind die Organe gegenüber dem Positionsfeld. So entsteht der Kreis des Lebens, dessen eine Hälfte vom Organismus, dessen andere vom Positionsfeld gebildet wird“ (ebd. 192). Stofflich-energetisch gesehen kommt nur dem Lebenskreis „Autarkie“ zu, während sich die „Autonomie“ des Organismus durch Heteronomie vermitteln muss: Der Organismus ist Einheit nur „durch Anderes, als er selbst ist“: Auf diese Weise ist er ,in ihm vermittelter Körper, Glied eines Ganzen, das über ihm hinausliegt“ (ebd., 195), d. h. in seiner Umwelt.

Der lebendige Körper setzt sich in sich in Organisation und außer sich in Position, deren Zusammenspiel nicht beliebig sein kann. Seine Organisation muss in sich gegensinnige Teilprozesse des Auf- und Abbaus ermöglichen: Die „Eigenzone, ungeachtet ihrer Entgegengestelltheit gegen die Fremdzone, zerfällt in ihr selbst, um dadurch die Verbindung mit der Fremdzone herzustellen“ (ebd., 196). Der Erweiterung des Lebens über den individuell lebendigen Körper hinaus entspricht auf der anderen Seite des Spektrums eine „kompensatorische Erneuerung“ durch Zellteilung (bei Einzellern) oder Bildung von Keimzellen und deren Befruchtung: „Das Individuum verjüngt sich also in einem anderen 
Individuum“ (ebd., 213). Man sieht hier, wie Plessner den Ausgangpunkt vom individuell lebenden Körper durch die Grenzhypothese immanent erweitert, also nicht im methodischen Individualismus stehen bleibt. Das ganze Spektrum des Zusammenspiels der Organisations- und Positionalitätsformen wird in den Biowissenschaften evolutionstheoretisch nach den Mechanismen der Anpassung und Selektion erklärt. Das naturphilosophische Vorverständnis kann hier nicht nur empiristische Missverständnisse, sondern auch den politischen Missbrauch evolutionstheoretischer Begriffe kritisieren, so die Übertragung des sozialdarwinistischen Kampfs ums Dasein in die Biologie.

Der Grenzübergang des lebendigen Körpers zu den ihn umgebenden Medien ermöglicht ein Spektrum zwischen seiner Öffnung und Schließung gegenüber der Umwelt. Folgt seine Organisation primär einer offenen Form, so wird er in all seinen Lebensäußerungen „unmittelbar seiner Umgebung eingegliedert“ und zu einem „unselbständigen Abschnitt des ihm entsprechenden Lebenskreises“ (ebd., 219). Diese offene Organisationsform wird phänomenologisch anhand von Pflanzen vorgestellt. „Geschlossen ist diejenige Form, welche den Organismus in allen seinen Lebensäußerungen mittelbar seiner Umgebung eingliedert und ihn zum selbständigen Abschnitt des ihm entsprechenden Lebenskreises macht“ (ebd., 226). Die geschlossene Organisationsform begegnet phänomenologisch in der Anschauung von Tieren. Die zentralnervöse Vermittlung des Antagonismus zwischen sensorischen und motorischen Organen im Inneren ermöglicht verschiedene Funktionseinheiten in der äußeren Positionierung (ebd., 244). Erst die zentrische Zuordnung zwischen Reiz und Reaktion vermittelt die Antwort auf die Verhaltensfrage durch eine „Unterbrechung“, d. h. durch einen Hiatus (raumhaft) und eine Pause (zeithaft), im Zentralorgan des Gehirns (ebd., 245, 260). Mit dieser Abhebung des Zentralorgans vom Gesamtkörper, zu dem es in der Organisation doch gehört (ebd., 243), korrespondiert in der Positionierungsweise die spontane, ein „handelndes Subjekt“ ausmachende Kontaktaufnahme in seinem Positionsfeld: Es eröffnet sich ihm eine, zwischen „Merken“ und „Wirken“ (ebd., 232) „bewusst“ werdende, „dingliche Gliederung der Umwelt“ (ebd., 252), zu der auch soziale „Mitverhältnisse“ (306-308) der leiblichen „Koexistenz“ (ebd., 259) gehören. Diese Art und Weise, psychisch durch ein Bewusstsein und physisch durch ein Gehirn vermittelt zu leben, nennt Plessner eine zentrische Positionalitätsform, die charakteristisch sei für die „Sphäre“ höher entwickelter Tiere (ebd., 237, 270-272). 


\subsection{Die exzentrische Positionalität kann wirklich die Lebenssphäre von Menschen oder anderen Personen ermöglichen (Plessner)}

Im letzten Kapitel seiner Naturphilosophie fragt Plessner danach, wie es möglich war, dass moderne Experten (Biologen, Naturphilosophen) und interessierte Laien implizit an den bisherigen Unterscheidungen in der Natur mitwirken und sich am Streit über ihre beste Explikation beteiligen konnten. Dafür war und ist ein grundsätzlicher Abstand von der zentrischen Positionalitätsform erforderlich, so sehr unsere Leiber mit den Leibern insbesondere von Menschenaffen spontan mitgehen und sie fehlbar verstehen können. ${ }^{2}$ Diese Distanz gegenüber der zentrischen Positionalitätsform nennt Plessner die exzentrische Positionalitätsform. Sie setzt einen „Bruch“ mit der zentrischen Positionalitätsform voraus und antwortet auf diesen „Hiatus“ (Plessner 1975, 292). Angesichts dieses Problems geht Plessners Naturphilosophie über in seine Philosophische Anthropologie. Damit erreichen wir Plessners theoretisches Äquivalent für Deweys dritte Ebene und Deweys These, das Ganze der Natur bleibe der menschlichen Existenz in unauflöslichen Differenzen eine Unbekannte.

Wie lässt sich der Unterschied und Zusammenhang zwischen den ,exzentrischen“ und den „konzentrischen“ Potenzialen, sich in einer Welt zu positionieren, verstehen (ebd., 294)? Nach dieser Verschränkung, die spezifisch personales Leben ermögliche, wird in der exzentrischen Positionalität (291-192) gefragt. Konzentrik heißt, dass das Zentrum der Positionierung (nicht das Zentrum des Organismus) in der funktionalen Mitte zwischen dem Organismus und seiner Umwelt liegt, z. B. da, wo der Bär im Fluß den Lachs gerade schnappt. Exzentrik bedeutet, dass die Verhaltensbildung raumhaft von außerhalb dieses leiblichen Zentrums und zeithaft aus ihm versetzt (vor und nach dieser Spontaneität) erfolgen kann. Wie ist dies auf wirkliche Weise möglich? - Nun dadurch, dass diese Lebewesen als Personen aus ihren konzentrischen Einheiten mit der Umwelt heraustreten. Insofern sie in Relationen $\mathrm{zu}$ anderen Personen eintreten, können sie von diesen Anderen her zu sehen, zu hören, zu fühlen erlernen, auch ihre eigene Konzentrik von außerhalb erlernen. Auf diesem Wege finden sie einen Abstand zu ihrer natürlichen Umwelt. Sie können diese Umwelt in eine Welt anheben und in diesem Rahmen zwischen „Außenwelt“, „Innenwelt“ und „Mitwelt“ (293-304) unterscheiden.

2 Siehe zum Vergleich zwischen Menschenaffen und Menschen Tomasello 2008. Vgl. zu den Gemeinsamkeiten und Unterschieden der Forschungsprogramme von Tomasello und Plessner Krüger 2016a. 
In dem exzentrischen Weltrahmen nimmt die Einrichtung von leiblich nötiger Umwelt für die Personen einen Aufgabencharakter an. Was habituell an natürlicher Eingespieltheit nötig ist, gilt es erst künstlich durch Kultur und Technik herzustellen. Diesen Weg nennt Plessner den der „natürlichen Künstlichkeit“ (ebd., 309). Es sei für exzentrische, also personale Lebewesen, natürlich, sich auf eine künstliche Weise durch kulturelle und technische Vermittlung zu verhalten. Anders könnten sie sich nicht mehr verhalten, weil sie infolge des Hiatus über keine ausreichend spezielle Anpassung an eine spezielle Umwelt verfügen. Gleichwohl müsse diese Künstlichkeit natürlich im Sinne der Konzentrik des Leibes gelebt werden können, woraus eine ständige Spannung erwachse. Was intentional hier und heute wie selbstverständlich solchen Lebewesen eine Erfüllung bietet, hat einen langen geschichtlichen Umweg hinter sich und vor sich. Diese Erfüllung brauche die Erfindung und Entdeckung von stabilisierbaren Vermittlungen, die sich verselbständigen können. Dieser Weg wird als der der „vermittelten Unmittelbarkeit“ oder der ,indirekten Direktheit“ (ebd., 321) bezeichnet. Man vergisst in der Generationen übergreifenden Folge von symbolisch-praktischer Habitusbildung, welche Antworten zu welchen Fragen gehörten und umgekehrt. Umso stärker werden Erinnerung und Tradition ausbildet, wogegen sich wieder Neuerungen in der Geschichte wenden. So entsteht stets von neuem das Problem, wie die nötigen Vermittlungen und Indirektheiten doch unmittelbar und direkt gelebt werden können. Schließlich bleibe Lebewesen in einer exzentrischen Positionalität bei allen künstlichen und geschichtlichen Erfolgen die Widrigkeit ihres Lebens, von der Krankheit bis zum Tod, nicht erspart, auch wenn sie besser behandelt und aufgeschoben werden können. Was Bejahung eines - gerade für Personen - widrigen und sterblichen Lebens im Letzten ermöglicht, sei ein über sie hinausgehender „utopischer Standort“" (ebd., 341). Aber dieses Nirgendwo und Nirgendwann der Zukunft werde positiv ausgemalt, könne in der Generationenfolge nicht immer dasselbe sein, sei umkämpft, werde in Frage gestellt und wiederbelebt. Der utopische Standort schwanke selber in der Geschichte der Generationen zwischen dem Nichts des Nihilismus und der absoluten Transzendenz monotheistischer Weltreligionen.

Einerseits besteht in der exzentrischen Positionalität also die nötige Möglichkeit, das Verhalten über die Relationen zwischen Personenrollen hinausgehend immer weiter in eine immer ferner werdende Welt zu ex-zentrieren, was Geist in Symbolformen ermöglicht. Andererseits bleibt aber zugleich der Rückbezug der Personen auf die Konzentrik ihrer Körperleiber die nötige Möglichkeit, sich im Gegensinn zu verhalten. Die personale Re-zentrierung auf die leibliche Konzentrik zwischen Organismus und Umwelt bleibt nötig, denn Lebewesen 
werden keine reinen Geister. Geist ist öffentlich mindestens auf eine praktisch geteilte Symbolik dreistelliger Relationen in triadischen Beziehungen zwischen Personen (ebd., 300-304, 340) angewiesen. Plessners Naturphilosophie endet mithin nicht in einem fertigen Verhaltensrepertoire, sondern in einem Bruch (ebd., 292-293), der personales Leben in Frage stellt. Es handelt sich um diejenige Art und Weise von Leben, die sich schon immer vorab zu der Aufgabe wird, Exzentrik und Konzentrik im positionalen Vollzug verschränken $\mathrm{zu}$ müssen, ohne dafür eine endgültige Lösung haben zu können, obgleich sie hier und jetzt eine $\mathrm{zu}$ vollziehen hat. Hier entsteht eine neue Antinomik, die Plessner nicht mehr in der Naturphilosophie, sondern in der Sozial- und Kulturphilosophie und schließlich in der Geschichtsphilosophie in anders gearteten Prozessen formiert sieht, weshalb man insgesamt von einer Philosophie der „Negativität des Absoluten“ sprechen kann (Krüger 1999).

Für heute muss es reichen, dass Plessner in der natürlichen Künstlichkeit, der vermittelten Unmittelbarkeit und dem schwankenden utopischen Standort drei unauflösliche Differenzen formuliert, die denen der menschlichen Existenz bei Dewey entsprechen. Entfallen diese Differenzen, weil man nicht mehr die Exzentrierung und die Rezentrierung des Verhaltens auszugleichen vermag, dann erfahren personale Lebewesen ihre Verhaltensgrenzen. Exzentrierung und Rezentrierung fallen dann auseinander, verselbständigen sich gegeneinander, die Exzentrierung im ungespielten Lachen, die Rezentrierung im ungespielten Weinen (Plessner 1970), bis diese so undifferenzierte Existenz im Ganzen ihrer Unergründlichkeit begegnet. Plessner hat seine Philosophische Anthropologie unter das Prinzip dieser Unergründlichkeit der Menschennatur im Ganzen gestellt, wodurch sich der Einsatz für eine bessere Zukunft dieser geistigen Lebensform lohne, statt ihr im Kampf für totalitäre Ideologien ein apokalyptisches Ende zu bereiten (Plessner 1981d u. 1983d). Plessner überlebte NaziDeutschland durch seine Emigration in die Niederlande (1934-1951). 